\title{
International and National Provisions of Space Law Regulating the Use of Outer Space
}

\author{
Oleksandr Kobzar
}

\author{
Doctor of Law, \\ E-mail: kaf forever@i.ua \\ https://orcid.org/0000-0002-5422-235X
}

\begin{abstract}
Anna Danylenko
Postgraduate Student, Scientific Institute of Public Law (Kyiv, Ukraine)

E-mail: danilenko07@bigmir.net

https://orcid.org/0000-0001-8263-1364
\end{abstract}

\begin{abstract}
In the article, the authors reveal the role and place of international and national provisions of law in regulating the use of outer space under the new scientific paradigm of outer space. The authors prove that the new technologies of using outer space contradict the existing international sources of space law. Consequently, the spacefaring nations independently approve the national legislation. However, sometimes the national provisions of space law of one State are not recognized by other spacefaring nations. This leads to intergovernmental political tension. The authors offer possible solutions to this problem.
\end{abstract}

Keywords: international law, space activities, outer space, international guarantees, provisions of law, public administration.

Received: March 01, 2019; accepted: April 07, 2019

Advanced Space Law, Volume 3, 2019: 48-62.

https://doi.org/10.29202/asl/2019/3/4

\section{Introduction}

What is outer space? Can it exist without Man, and if so why? What is the essence of human relations in space? What place do provisions of law occupy in public space relations? It would seem that these questions are distant for an average person and relate exclusively to scientific considerations of highly specialized experts. However, probably, sometimes gazing at the starry sky, every representative of humankind thought at least once about why, how and when space arose. What place does a person take in it? What future destiny is expecting humanity in it? How can it be used in favour of oneself and others? As soon as people moved from abstract

(C) Kobzar, Oleksandr, 2019

(C) Danylenko, Anna, 2019 
thinking to the practical peaceful use of outer space, space law was born. This happened on October 4, 1957, when the first satellite flew around the planet Earth to a height of more than 200 kilometres over the state borders of sovereign States. Neither of them voiced protest to the State, which owned the first satellite, that led to the occurrence of the first provision of space law, "instantaneous principle", that is, each country has the right to launch civilian satellites to the near-Earth orbit without asking permission of other States.

Previously, the millennial human endeavours were aimed at the first considerable breaking off from the surface of the earth, and then going into outer space. It should be noted that Nazi Germany's ballistic missiles FAU 2 were the first to reach space. However, those events were not related to space law, since they were regulated by the Geneva Convention.

After the launch of other artificial satellites into space, an objective need for a systematic, integrated, planned and well-considered study of outer space based on certain worldrecognized community provisions of law occurred. For example, in the second half of the twentieth century, the so-called spacefaring nations, which had a real or potential resource to launch spacecraft, began to sign international space agreements that formed the provisions of international space law. For almost six decades, they provided legal regulation of the exploration and use of outer space.

In addition, it should be determined that these agreements are normative principles. For their execution, no "space police" and "space court" were created. The only effective means of responding the violation of the provisions of international space law should have been sanctions that the UN Security Council could apply to the offender State.

Despite such international legal imperfection, no country has formally violated them for now. This is due to not only the high international legal culture of the leaders of spacefaring nations, but also to the blurriness of the principles/provisions of international space law that enables spacefaring nations to operate in space, not violating the provisions of international space law formally.

The abovementioned, as well as private companies access to outer space, the growth of their technological capabilities, the expansion of human knowledge about space and its possible use, substantiate the relevance of this article.

Accordingly, the authors analysed the impact of new knowledge about space and new technologies on the development of international and national space provisions. This topic is crucial, because the development of knowledge about space and new space technologies outgrows greatly the development of provisions of law in this area, which leads to international political tension between States, and as a result may lead to international conflicts.

\section{Impact of new space knowledge on the development of provisions of space law}

Cosmology is a prognostic science, achievements of which indicate that the universe is expanding at an ever-greater rate, through the so-called "dark energy" [Bazaluk \& Kharchenko, 2018: 11]. It is believed that it began with the Big Bang of something at a specific moment. First, this impressive hypothesis appeared in a scientific form in 1931 in the article by Georges Lemetra, a Belgian cosmologist and a Catholic priest. Nowadays, this theory is accepted by almost all astronomers. It is a radical shift from scientific orthodoxy in the 1930s. At that time, many astronomers did not still like the idea that the universe was expanding. The fact that the entire observed world galaxy began with an explosion seemed to be meaningless [Soter \& Tyson, 2000]. 
Moreover, exploration of outer space and the universe were and are priority and authoritative for countries with advanced economic and space industries, because this activity is socially significant and far from everyone who wants can join it. According to Guillermo Söhnlein, Chairman of the International Association of Space Entrepreneurs: "If you're not sure internally why you exist, it's very difficult to expect anyone outside to understand why you exist" [Foust, 2006].

In the past decade, a telescope-satellite HABL, which, in particular, discovered thousands of new exoplanets, worked extremely well. Definitely confirming the hypothesis of scientists, that planets are not that uncommon in the orbits of other stars. In the current conditions, the space CHIP-ship is already being planned to get to the star nearest to the Sun, Alpha Centauri, in 20 Earth years. Evidently, the law, as the regulator of all social relations, cannot ignore such cognitive activity. Objectively, any social relations between people require legal regulatory basis. With demand for the exploration and use of outer space, a normative fixator for the development of such relations, which developed, renovated and transformed rather rapidly, became necessary.

Therefore, in the medium term, such actions will lead to strengthening of national space provisions, and private international space law [Halunko \& Didenko, 2019: 18]. For any country's budget, the conduct and implementation of space projects is a serious financial test, therefore, it will be necessary to combine the efforts of many spacefaring nations and private space companies of different countries. Therefore, the adoption of new common rules, both for public and for private subjects of space law, is a necessity of the present, since the activities of the former are governed by the provisions of international space law and the activities of latter - by the future provisions of international private space law.

It is evident that for private companies, from the perspective of the use of outer space, the development of technologies for the extraction of minerals from asteroids is more relevant. As a result, a number of issues arise to be resolved, namely, the problems of legislative consolidation of the ownership of mining deposits. In the United States, ownership of mining space resources is already guaranteed by national law. Beyond doubt, this is a better way than the absence of space provisions in this area at all. However, if other states act in this manner, legal conflicts will arise definitely leading to legal outer space conflicts.

This challenge needs to be addressed at the level of the development, adoption of an appropriate international treaty by the UN and its ratification by the vast majority of spacefaring nations. This study reveals that at the present stage, the adoption and ratification of this international treaty is of high probability.

Another legal challenge to be regulated by space law is a significant reduction in the cost of placing in orbit around the earth of Internet satellites and other small satellites. This state of affairs leads to: first, the space becomes clogged; second, astronomers complain, since the "armada" of these satellites and the space debris after their launch overlaps the possibility of visual exploration of outer space; third, the introduction of a "sovereign" Internet requires a new perspective at the priority of the instantaneous cosmic principle.

\section{Legal regulatory basis of space relations: necessity or encumbrance?}

Let us return to the eternal question: Are space relations subject to legal regulation? Who and how does it? And the most important question — why? 
On the one hand, these questions are primitive and meaningless from the perspective of the law theory and the international law theory. However, from the perspective of the legal principles, each country should establish legal regimes for the existence, development, protection and security of public goods and international achievements, focusing on the interests of humanity, rather than relying on its own narrow interests of the country. However, in practice, most cases show that the opposite is true. Despite the diversity of democratic and non-democratic States in terms of state-legal nature, from the perspective of their activities in the international arena, including in outer space, the difference is insignificant. Each sovereign State defends its interest, and in the context of commercialization of outer space, economic interest comes first.

Space is not only something unknown, untouched by an ordinary person, it is primarily a value. It is a potential value, as long as humanity has no technology to use it, and a real material value, as soon as such technologies appear. As is known, values require special attention of the authorities. Moreover, in the course of discovering something unfamiliar it can be easily harmed, even by accident, without realizing the consequences. For a reason, there is a hypothesis that maximum efficiency in a certain activity can be achieved by the "trial-anderror" method. However, outer space cannot be studied in this way. Only well-considered, concerted action by special international, national and private institutions can be involved in the exploration of undiscovered outer space, the moon, and other celestial bodies.

Accordingly, what legal regulatory framework for space relations should be: total or liberal? Comprehensive or selective? Or where is the intermediate truth that will ensure the effectiveness of management decisions regarding the admission of humanity's messengers into space and provide them with the necessary conditions for achieving their goals?

Legal treatment of space relations is carried out at two levels: international and national. At the first level (international), in the area of international issues, the UN regulates the introduction of a uniform legal regime, common for all. At the second level (national), each specific state, represented by its public administration bodies authorized by it, intricately specifies and broadens space provisions regarding the use of outer space, in general, and space objects with mineral deposits, in particular.

The international community has chosen a vector for settlement of these relations more similar to a comprehensive one, but without specifying that enables the national public administration to apply administrative tools. However, in line with general provisions, there are prohibitions mandatory for observance and enforcement. In this way, the performance of the subjects of these relations is determined, thus the regulatory, protective, security and defensive functions are implemented to guarantee the legitimate interests of all humanity.

Accordingly, legal treatment is quite diverse and is used to establish and implement a regime in the area under consideration. One of the main legal treatment is the regulatory basis, reduced to a legal provision and reflected in space law. Thus, space legislation is founded on the regulatory legal basis, which, in turn, is formed by a number of international provisions and supplemented by national, mostly public legal provisions, since the activity under consideration is carried out on behalf and in the interests of the State or the international community.

For example, according to the Law on Space Activities of the Russian Federation № 56631 (1993 with amendments), space relations are regulated in accordance with the Constitution of the Russian Federation, generally accepted principles and provisions of international law and international treaties of the Russian Federation, as well as this Law and other federal laws, legal regulations of the Russian Federation [Law, 1993]. 
Therefore, the current legal regulatory basis of space relations has at least two conceptual approaches: first, the priority of international institutions (or the concept of world security) in the aspect of the exploration of outer space by various methods; the second, the concept of self-sufficiency of national States, as a way of autonomous resolution of issues relating to the implementation of space activities by an individual State, its citizens or enterprises. According to the practice of space law, the first concept should be dominant, since the security of humankind is the fundamental rule of coexistence of peoples, nations and States. However, owing to the primacy of internal problem resolution for sovereign States, while international problems are secondary for them, as well as the lengthy adoption of an international legal act, the development of space law is now carried out on the basis of the adoption of new national space provisions of law by States.

Therefore, the mechanism of the legal regulatory basis of outer space is a set of: 1) declared international guarantees of space exploration, based on its recognition as a value that cannot be nationalized, assigned or damaged; 2) national legal treatment of space relations that arise during space activities by a particular country or its representatives; 3 ) provisions of private space law, which is at the stage of formation.

\section{International provisions of the exploration and use of outer space in the modern paradigm}

In 1959, a major event was the creation of the United Nations Office for Outer Space Affairs (UNOOSA). Thus, the necessity of international cooperation in outer space was determined. Almost 10 years later, in 1967, for the first time, a specific agreement was signed on space exploration, the Treaty on Principles Governing the Activities of States in the Exploration and Use of Outer Space, including the Moon and Other Celestial Bodies (TPGASEUOS). Formally, this Treaty concerned precisely outer space and established the legal framework for its regulating, but its decisive focus was on establishing the principles of States' activities. Therefore, a "sub-monopolistic" model of the legal regulatory basis of space relations was applied, that is, an attempt was made to fix an international regime for the exploration of outer space without establishing appropriate mechanisms for total regulation, by declaring the fundamental principles for such activities.

Moreover, the adoption of outer space Treaty marked two important points in the history of international law, namely: the official recognition of a separate legal regime for performing space activities; the creation of the first normative document that proclaims outer space and its celestial bodies as the value and the good of humanity. The value of the Treaty is confirmed by its modernity, even over five decades after its entry into force, due to its general set of principles [Stefoud, 2017].

The Treaty under study was largely based on the Declaration of the Legal Principles Governing the Activities of States for the Exploration and Use of Outer Space adopted by the General Assembly, but several new provisions were added. The Treaty was opened for signing by the three depository governments in January 1967, and came into force in October 1967.

Due to signing the Treaty at the time of the initiation of national space activities and its addressing the issues that might arise in the development of space technology, it had general provisions in essence [Grush, 2017]. Its provisions were elaborated and clarified later with the adoption of other space treaties [Stefoud, 2017]: the Agreement on the Rescue of Astronauts, the Return of Astronauts and the Return of Objects Launched into Outer Space no. 2345 (XXII) 
of 1967, the Convention on International Liability for Damage Caused by Space Objects no. 2777 (XXVI) of 1971 and the Convention on Registration of Objects Launched into Outer Space no. 3235 (XXIX) of 1974, and others [Grush, 2017].

For clarity, it should be noted that the fundamental principles of the activities of States on the exploration and uses of outer space are: 1) the activities shall be carried out for the benefit and in the interests of all countries and shall be the province of all mankind; 2) outer space shall be free for the exploration and uses by all States; 3 ) outer space and its celestial bodies shall not be subject to national appropriation by claim of sovereignty, or by means of use or occupation, or by any other means; 4) States shall not place nuclear weapons or other weapons of mass destruction in orbit or on celestial bodies or station them in outer space in any other manner; 5) the Moon and other celestial bodies shall be used exclusively for peaceful purposes; 6) astronauts shall be regarded as the envoys of mankind; 7) States shall be responsible for national space activities whether carried out by governmental or non-governmental entities; 8) States shall be liable for damage caused by their space objects, and States shall avoid harmful contamination of space and celestial bodies [Resolution, 1967].

The rapid development of research and cognitive activity of outer space and its bodies has encouraged the international community to efficient normative regulation of the activities of States in this area. The signing of a joint agreement between powerful States-leaders in this period began a new era of mankind, that is, the study and understanding of not only visible, but also all-embracing, unknown space. The principles enshrined in the Treaty are nothing more than a supranational source of space law, which initiated it as a sectoral and scientific course.

Evidently, the above sources of international space law do not take into account modern challenges. Obviously, society, the State, and space activities in particular, are not static and when they change the law often remain as "a rigid exo-structure" that no longer suits the existing regulatory model of space relations [Blount, 2011]. For example, such challenges include: outer space boundaries definition, space debris minimization, new research regulation, the peculiarities of intellectual property rights to space resources, and some others.

Therefore, the regulatory framework for space international law needs to be updated as it no longer controls the dynamics of space activities. Evidently, since the first acts have been adopted, space legislation is being updated gradually, for example, there are relatively modern international acts, such as Recommendations on enhancing the practice of States and international intergovernmental organizations in registering space objects no. 62/101 (2007); Recommendations on national legislation relevant to the peaceful exploration and use of outer space no. 68/74 (2013); Declaration on the fiftieth anniversary of the Treaty on Principles Governing the Activities of States in the Exploration and Use of Outer Space, including the Moon and Other Celestial Bodies no. 72/78 (2017). However, most of the modern issues are still out of the focus of international space law, as are not subject to it.

Consequently, the international provisions on the exploration and use of outer space are international guarantees of outer space development, that is, a set of consistent, rigid rules providing for that outer space and its celestial bodies are free from any conflict situations based on the responsibility for unlawful actions, including violations of the procedure for research activities and the use of outer space for other purposes. In the modern paradigm of scientific knowledge of outer space, they need to be updated in the aspect of their flexibility and adaptability to the practical challenges of the present. 


\section{The role of national provisions of space law in regulating space relations}

More than 50 years ago, since outer space had been recognized as the object of regulation, national legislation of a given country began to gain momentum. Globally, outer space was regulated by international law. That is, all countries and parties had to work together to develop effective space legislation for future needs [Doldirina, 2018]. States that have developed national space legislation apply a number of different approaches to regulating such activities. National space laws may be contained in unified acts or in a combination of national legal instruments. In addition, some States have adapted their national legal frameworks to meet the specific needs and practical considerations of the scale of their space activities and the level of involvement of non-governmental organizations.

A number of issues are subject to regulation, including the launch of space objects and their return from space, the operation of a launch or re-entry site, and the operation and control of space objects, and others. Moreover, it should be noted that States include the obligation to resolve and control the activities of non-governmental organizations in outer space, as well as establish administrative and legal mechanisms for regulating national commercial space activities.

Therefore, the national principles of regulatory basis of space relations are a set of administrative actions of a particular public administration regarding the regulation of carrying out space activities by a particular country or its representatives in the form of legal means of diverse significance, origin and legal force. Further, national legal treatment of space relations will be considered on the example of space law of individual countries.

\section{Progressive national provisions of the United States of America space law}

A distinctive feature of U.S. national space law is the trend to adjust to the development of space technology and geopolitical events. Following the successful launch of the satellite in 1957, the United States removed the legal vacuum that existed for space activities then by adopting its own national legislation and encouraging the world community to create space law at the international level. As a result, the National Aeronautics and Space Act of 1958 was adopted, since then the U.S. National Space Law continued to evolve [Gabrynowicz, 2010: 405].

One of the recent significant developments in space law of this country was the recodification of the current legislation concerning national and commercial space programs in the form of a new title of the Code of the United States. Thus, Title 51 of the U.S.C [Smith, 2018: 43] was put into effect. Accordingly, legal framework for outer space activities is Title 51 of the U.S.C., as well as 14 C.F.R. 400-499; NPR 8715.6A; NASA-STD 8719.14; U.S. Government Orbital Debris Mitigation Standard Practices; Title 47 of the U.S.C.; 47 C.F.R. Parts 5, 25, and 97; Order, FCC 04-130; 47 C.F.R. 25.160-162 [A/AC.105/C.2/2014/CRP.5, 2014:9].

Title 51 of the U.S.C provides for that the public administration is represented by the National Aeronautics and Space Administration. However, apart from this public body, the regulation of space relations is carried out in individual aspects by National Aeronautics and Space Administration, National Oceanic and Atmospheric Administration, Office of Science and Technology Policy, civilian agency exercising control over aeronautical and space 
activities, Department of Defense. The latter is responsible for performing activities associated with the development of weapons systems, military operations, or defence of the United States (including the research and development necessary to make effective provision for the defence of the United States).

In the aspect under study, the U.S. legal regime concerns: 1) space control; 2) satellite land remote sensing; 3) communications satellites; 4) national aeronautics and NASA activities; and 5) space exploration. Most of these issues are addressed by space policy, implemented through relevant programs that provide specific administrative rules for its implementation [Milton, 2018: 43].

Accordingly, legal provisions regulates space relations such as: 1) the development of State space policy and implementation of space programs; 2) the improvement of the usefulness, performance, speed, safety and efficiency of aeronautical and space vehicles; 3 ) the development and operation of vehicles capable of carrying instruments, equipment, supplies and living organisms; 4) the establishment of long-range studies for aeronautical and space activities for peaceful and scientific purposes; 5) the development of commercial possibilities, search and encouragement of the commercial use of space (the establishment of the legal framework for space trade, transportation, space commercialization control); 6) the implementation of appropriations and incentive measures in the form of awards, grants for training, scholarships; 7) licensing, insurance; 8) safety and health protection; 9) the development and implementation of the policy of land remote sensing; 10) the interagency coordination of civil and military administration; 11) the cooperation of the United States with other countries and organizations in this area [U.S., 2010], etc.

\section{Subordinate provisions of space law of China}

Legal regulatory basis of space activities in the China is based on Measures for the Administration of Registration of Objects Launched into Outer Space of 8 February 2001; Interim Measures on the Administration of Permits for Civil Space Launch Projects of 21 December 2002; Interim measures on Administration of Mitigation of and Protection against Space Debris [A/AC.105/C.2/2014/CRP.5, 2014: 5]. In other words, the legal basis is not laws, but subordinate legal regulations. The China does not have a specialized space law, and in the near future it is unlikely to be developed and adopted, however, it does not prevent China from being the third country that sent people to space in 2003 [Jones, 2019].

The Chinese government regards the space industry as an important part of the overall development strategy of the country and adheres to the principle of the peaceful exploration and use of outer space. Over the past 60 years, since the creation of the space industry in 1956, China has made great achievements in this area, including the development of missiles and artificial satellites, the implementation of manned space flights and lunar probes. This enabled China to develop the autonomy space industry, to introduce innovations. China's space industry is subject to and serves the national development strategy and adheres to the principles of innovative, coordinated, peaceful and open development [The State, 2016]. The public administration is represented by China National Space Administration (CNSA), responsible for civilian space activities and for international space cooperation with other countries, and also performs the relevant government functions [China, 2018], and State Administration of Science Technology and Industry for National Defence, Commission of Science Technology and Industry for National Defence (COSTIND), responsible for the 
regulation and management of projects for the launch of civilian space objects, civil space development, national security and public interest protection, fulfilment of obligations of China under international conventions on space [A/AC.105/C.2/2014/CRP.5, 2014:5].

In the aspect under study, the legal regime of the PRC concerns the regulation and organization of: 1) the space transport system;2) artificial satellites, such as Earth observation satellites, communication and broadcasting satellites, satellites of navigation and positioning, new technological tests of satellites; 3) manned space flight; 4) space exploration; 5) space launch pads; 6) space telemetry, tracking and control (TT \& C); 7) the implementation of space programs; 8) the space science development, that is, satellites of space science, space environment of scientific experiments, detection and forecasting of space environment; 9) space debris minimization [The State, 2016].

Accordingly, legal treatment of space relations is the application of registration and licensing procedures; expert and approval measures; the study and formulation of policies and regulations in the space industry, implementation of programs and plans for its development; the organization and implementation of large space projects and programs; the supervision of civilian space research projects; the management of international space exchanges and cooperation, as well as participation in relevant international organizations and their activities on behalf of the Government of China [China, 2018], etc.

Over the next five years, China plans to accelerate the development of its space activities by increasing the main capabilities of its space industry, strengthening research in key and advanced technologies and implementing manned space flights, exploring the Moon, and carrying out other important projects. In addition, the country is going to start new key scientific and technical programs and major projects to complete its space infrastructure system, expand the scope of space technology and space science [The State, 2016].

\section{National legal provisions of space law of Germany}

The legal basis of space activities in Germany is Raumfahrtaufgabenübertragungsgesetz 22 August 1998, BGB1. I, 2510 (Delegation of Space Activities Act); Telekommunikationsgesetz, 22 June 2004, BGB1. I, 1190 (Telecommunications Act), as amended 7 August 2013, BGB1. I, 3154 [COPUOS, 2015]; Act to give Protection against the Security Risk to the Federal Republic of Germany by the Dissemination of High-Grade Earth Remote Sensing Data (Satellite Data Security Act — SatDSiG), 2007 [A/AC.105/C.2/2014/CRP.5, 2014:5].

The public administration is represented by the Space Administration of the German Aerospace Centre (DLR), the national centre for aeronautics and space research of the Federal Republic of Germany. Research and development in aeronautics, space, energy, transport, digitization and security are integrated into national and international joint ventures. DLR is responsible for the planning and implementation of the German space program [German, 2019], which includes: Germany's participation in the ESA and the EUMETSAT; the implementation of the projects of the National Program, and the Space Research and Development Program of the DLR through institutional support from federal and land authorities. The main participants in the space program are the Ministry of Education and Science, the Ministry of Transport, Building and Housing and the Ministry of Defence. These efforts are complemented and accompanied with space exploration by Max-Planck, the Helmholtz Centres, the Deutsche Forschungsgemeinschaft (German research community) as well as university research units and institutes [Bulmahn, 2001: 5]. 
In the aspect under study, the legal regime concerns the regulation and organization of the general, economic and scientific sides of space relations. For example, State support for space research is directed at projects offering real economic opportunities for the branch development. Accordingly, it enables firms working in the space sector to build on the potential of the space industry to develop new commercial products and services. This will not only consolidate employment in the high-tech sector, but also create new jobs [Bulmahn, 2001:12].

National legal provisions of space law of Germany provide for that the main legal treatment of space relations, applied by the public administration is: the licensing of the operator's activities; the establishment of the operator's responsibilities, including the maintenance of documentation, registration procedures, provision of information, etc.; the implementation of control and supervision measures; the establishment of taxes and other fees; the imposition of compulsory measures, etc.

\section{National legal provisions of space law of the Russian Federation}

Nowadays, the Russian Federation remains a significant player in the use of outer space, second only to the USA and the PRC [Jackson, 2018]. Legal regulation of space activities is carried out on the basis of: "Law on Space Activity", Federal Law no. 5663-1 (1993, as amended); "Statute on Licensing Space Operations", Federal Government Decree no. 104 (1996) [document A/AC.105/C.2/2014/CRP.5, 2014:8]; "Regulations of Russian Space Agency", Resolution no. 468 of 15 May 1995; "Regulations of Russian Federation on Space Activities", Resolution no 314 of 26 June 2004; "Decree on Measures to Fulfil the Russian Federal Space Program and International Space Agreements”, Decree no. 422 of 12 April 1996; "Edict on the Organization of Further Utilization of the Baikonur Cosmodrome in the Interests of the Russian Federation's Space Activity”, Presidential Edict no. 2005 of 24 October 1994; "Edict on Structure of Management of Space Activities in Russian Federation", Presidential Edict no. 185 of 25 February 1992 [European, 2011].

"Law on Space Activity", Federal Law no. 5663-1 (1993, as amended) defines space activities as a priority and as any activities associated with the direct work on the exploration and use of outer space, including the Moon and other celestial bodies [Law, 1993].

The main areas of space activities include: scientific space exploration; the use of space technology for communication, television and broadcasting; land remote sensing from outer space, including state environmental monitoring and meteorology; the use of satellite navigation and geodetic systems; manned space flights; the use of space equipment, space materials and space technology in the interests of defence and security of the Russian Federation; the observation of objects and phenomena in outer space; testing of equipment in space; the production of materials and other articles in space; other types of activities carried out using space technology. Such activities include the creation (including the development, manufacture and testing), the use (operation) of space equipment, space materials and space technology and the provision of other space-related services, as well as the use of the results of space activities and international cooperation of the Russian Federation in the exploration and use of outer space [Law, 1993].

Russia considers outer space as a strategic region to build its military potential on Earth, provide intelligence and communication functions, and achieve international status and prestige as a spacefaring State. Its space strategy is an instrument to become a "great power" and to form an international system close to Russia's vision of a new, multipolar world. Space also provides Russia with economic benefits [Jackson, 2018]. 
The subjects that apply legal treatment to space relations in this country are the President of the Russian Federation, the parliament and the federal executive bodies on defence matters. A special subject is the State Corporation for Space Activities, "Roskosmos", which is the authorized body, responsible for space activities in the interests of science, technology and various branches of the economy, as well as for organizing work on the creation of space technology for scientific and socio-economic purposes and, together with the federal executive body on defence, space technology of dual use within the Federal Space Program and other federal programs in space activities.

The main legal instruments for the regulation of space relations are: the development and implementation of state policy on space activities, including the implementation of programs in this area; ensuring safety of space activities; cooperation with organizations of other States, as well as with international organizations on space activities; signing and ratification of the relevant international treaties in accordance with the established procedure; procedure for planning and operation of space equipment; organization and coordination of system exploration of outer space; licensing of space activities; control over certification and declaration of conformity of space equipment; carrying out expert work on matters relating to space activities; financing of space activities; registration actions concerning space objects of the country, and others [Law, 1993], etc.

\section{National legal provisions of space law of Finland}

The legal regulatory framework for space activities in Finland is based on the "Act on Space Activities" (63/2018). It came into force on January 23, 2018 and was supplemented by the same Decree of the Ministry of Economic Affairs and Employment on Space Activities (Ministry of Economic Affairs and Employment of Finland).

This law applies to space activities carried out throughout the State of Finland and beyond, if they continue on board a ship or airplane registered in Finland; or carried out by a Finnish citizen or a legal entity registered in Finland. The basic bodies of public administration that regulate relations in space activities are: the Ministry of Economic Affairs and Employment on Space Activities, which is responsible for the overall guidance, monitoring and development of space activities, as well as the Ministry of Defence, which is responsible for general guidance and supervision of space activities [Act, 2018].

Space law in Finland shall create a clear framework for the existence and development of the space industry, such as providing a favourable investment climate. The starting point is a positive approach to space activity (Ministry of Economic Affairs and Employment of Finland), that is, outer space can be used exclusively for peaceful purposes, but military operations that comply with the norms of the UN Charter and international law should not be banned.

In Finland, space activities may be carried on only subject to prior authorisation by the Ministry of Economy and Employment, which is granted for a definite or indefinite period. In addition, the public administration is authorized to apply the following legal measures on space relations: registration of space objects; implementation of procedures for prosecuting offenders in this area; compulsory insurance; conducting supervisory, inspection and control actions on operators' activities [Act no. 63, 2018], etc. 


\section{National legal provisions of space law of Australia}

Legal regulatory framework for space activities in Australia is based on the "Space Activities Act", Act no. 123 of 1998; "Space Activities Regulations" no. 186 of 2001, as well as "Space Activities (Approved Scientific or Educational Organisations) Guidelines" of 2015 [Department (1), 2019]. The first two regulatory documents relate, first of all, to launching and returning space objects.

On October 24, 2015, the Law on Space Activities of 1998 was revised to comply with technological advances and innovations in Australia's space potential [Department (2), 2017]. The last review was in 2018, when the Law amending the 1998 Space Act, concerning the facilitation and modernization of launching and returning of space objects, was adopted [Department (1), 2019].

Space law is applied to activities carried out throughout Australia and/or Australianregistered ships and aircraft or when one of the founders of a private space company is an Australian national. Space activities include the launch, operation or guidance of a space object, as well as the operation of space equipment. An operator of space activities is any natural or legal person that meets the requirements established in this law, has obtained permission for such activity and carries out or carried out space activities [Bundesgesetz, 2011].

The main subject of public administration in this area is the Minister, who applies legal treatment of space relations, such as granting permissive documents (for example, a space licence, a launch permit, an overseas launch certificate, etc.); appointing a Launch Safety Officer for each licensed launch facility; specifying fees and other obligatory payments; bringing to responsibility for damage caused by space objects; implementing agreements on space cooperation [Space, 1998], etc. It should be noted that this act is sufficiently detailed and provides for internal and external administrative mechanisms for regulation of space relations in the substantive and procedural aspects.

\section{Issues of the legal regulatory basis of the commercialization of the use of outer space}

In this study, the issue of the commercialization of space has been analysed, which is not surprising, as over recent years private investment in space resources has developed and domestic legislation aimed at protecting ownership of extracted resources has been adopted [Su, 2017: 991]. However, international provisions/guarantees do not establish a unified legal mechanism for regulating the commercialization of the use of outer space. Accordingly, the present space regime is unclear regarding the commercial exploitation of natural resources in outer space [Blount \& Robison, 2016]. Although the Outer Space Treaty contains provisions for the non-appropriation of outer space, it is not entirely clear whether extraction of natural resources from outer space is an integral part of the appropriation [International, 2015; Zhao, 2018].

It should be recalled that the United States initiated allowing U.S. citizens to profit from such commercial exploitation. It also paves the way for other countries such as Luxemburg [Foster, 2016] to take a similar position. It is too early to conclude whether this position should be welcomed, but such an action clearly demonstrates that national space law can play an important role in filling the gap in the legal regime and that it can provide a test ground for some new provisions [Zhao, 2018]. 


\section{Conclusions}

The present article reveals that the development of space relations is a dynamic process that always requires a systemic, balanced and timely response both at the international level and on the part of the individual country. The study represents the existence of outdated dogmatic understandings of certain provisions of international space law in the aspect of settling the latest challenges of the development of social relations in the space sector and the existence of advanced national space law of individual countries.

The authors find out that international institutions are focused on maintaining the peaceful use of outer space, but due to modern challenges, not all issues are regulated. Therefore, a new vector for the legal framework for individual space relations based on international private space law requires further substantiation and introduction. In addition, a unified system of informing the population about the real scientific and practical potential of outer space should be developed, because of the current negative attitude of the public regarding recognized and proven facts, and especially in connection with their reliability. Not least, this is due to the intention of countries to be spacefaring nations, the most authoritative players in this field.

Therefore, the dominant aspect of the exploration and use of outer space should be provisions of international space law adopted by the UN. However, due to the sovereign States' focus on the resolution of internal problems, nowadays the development of space law is based on the adoption of national laws and relevant subordinate legal regulations. It takes a great human and political will of the ruling elites of spacefaring nations to change this trend.

The authors argue that this issue should be well considered in the context of the mechanism of legal regulation of outer space. Namely, international and national guarantees of space exploration should be further developed by: the establishment of common provisions and the recognition of outer space as a value that cannot be nationalized, privatized or damaged (provisions of international space law); the national legal treatment of space relations that arise during space activities by a particular country or its representatives (provisions of national space law); provisions of private space law, which is at the stage of formation (provisions of international private space law).

\section{미] References}

Act on Space Activities. Law of the Finland № 63/2018, 2018. https://tem.fi/ documents/1410877/3227301/Act+on+Space+Activities/a3f9c6c9-18fd-4504-8ea9bff1986fff28/Act+on+Space+Activities.pdf

A/AC.105/C.2/2014/CRP.5. Schematic overview of national regulatory frameworks for space activities, 2014 http://www.unoosa.org/pdf/limited/c2/AC105_C2_2014_CRP05E.pdf

Bazaluk, Oleg, and Larysa Kharchenko. The Philosophy of the Cosmos as the New Universal Philosophical Teaching about Being. Philosophy and Cosmology, Volume 21, 2018: 6-13. https://doi.org/10.29202/phil-cosm/21/1

Blount, P. J. Renovating Space: The Future of International Space Law, 40 Denv. J.Int'lL. \& Pol'y. 515, 2011. https:/www.law.upenn.edu/live/files/7830-blountrnvtspcdnvrjintllawpolpdf

Blount, P. J., \& Robison, C. J. One small step: The impact of the U.S. Commercial Space Launch Competitiveness Act of 2015 on the exploitation of resources in outer space. North Carolina Journal of Law \& Technology. 18, 2016. 160-186. 
Bulmahn, Edelgard. German Space Programme. Bundesministerium für Bildung und Forschung, 2001. https://www.dlr.de/dlr/Portaldata/1/Resources/documents/drp-engl. pdf

Bundesgesetz über die Genehmigung von Weltraumaktivitäten und die Einrichtung eines Weltraumregisters (Weltraumgesetz). StF: BGB1. INr. 132/2011 (NR: GPXXIV RV 1466 AB 1585 S. 135. BR: AB 8628 S. 803.). https://www.ris.bka.gv.at/GeltendeFassung. wxe? Abfrage $=$ Bundesnormen $\&$ Gesetzesnummer $=20007598$

China National Space Administration. Organization\&Leader. CNSA, 2018 http://www.cnsa. gov.cn/english/n6465645/n6465650/c6768437/content.html?COLLCC=3470529681\&

COPUOS. Space Debris Mitigation Standards: Germany. Unoosa, 2015 http://www.unoosa. org/documents/pdf/spacelaw/sd/Germany.pdf

Department of Industry, Innovations and Science (1) - Australian Government. Space regulation, 2019. https://www.industry.gov.au/regulation-and-standards/spaceregulation

Department of Industry, Innovations and Science (2) - Australian Government. Reform of the Space Activities Act 1998 and associated framework, 2017. https://consult.industry. gov.au/space-activities/reform-of-the-space-activities-act-1998-and-associ/

Doldirina, Catherine. Outer space laws and legislation: regulating the province of all mankind. The Institution of Engineering and Technology, January 22, 2018. https://eandt. theiet.org/content/articles/2018/01/outer-space-laws-and-legislation-regulating-theprovince-of-all-mankind/

European Centre for Space Law. National Space Legislations. ECSL, $2011 \mathrm{https}$ ://www.esa. int/About_Us/ECSL_European_Centre_for_Space_Law/National_Space_Legislations

Foster, Craig. Excuse me, you're mining my asteroid: Space property rights and the U.S. Space Resource Exploration and Utilization Act of 2015. University of Illinois Journal of Law, Technology \& Policy, 2016, 407-430. http://illinoisjltp.com/journal/wp-content/ uploads/2016/11/Foster.pdf

Foust, Jeff. What's the value of space? The Space Review, June 19, 2006. http://www. thespacereview.com/article/644/1

Resolution adopted by the General Assembly 2222 (XXI). Treaty on Principles Governing the Activities of States in the Exploration and Use of Outer Space, Including the Moon and Other Celestial Bodies. Dec. 19, 1967. http://www.unoosa.org/oosa/en/ourwork/ spacelaw/treaties/outerspacetreaty.html

Gabrynowicz, Joanne Irene. One Half Century and Counting: The Evolution of U.S. National Space Law and Three Long-Term Emerging Issues. Harvard Law \& Policy Review. Vol. 4, 2010, pp. 405-426. http://joannegabrynowicz.com/wp-content/uploads/2013/11/2010Gabrynowicz-HLPR-4.2-405-426-US-Space-Law.pdf

German Aerospace Center. DLR at a glance. DLR, 2019 https:/www.dlr.de/dlr/en/ desktopdefault.aspx/tabid-10443/637_read-251/\#/gallery/8570

Grush, Loren. How an international treaty signed 50 years ago became the backbone for space law. The Verge, 2017. https://www.theverge.com/2017/1/27/14398492/outer-spacetreaty-50-anniversary-exploration-guidelines

Halunko, Valentyn and Didenko Serhii. Private International Space Law. Philosophical and Legal Factors of Approval by the World Community. Philosophy and Cosmology. Vol. 22. pp. 16-23, 2019. https://doi.org/10.29202/phil-cosm/22/2 
International Institute of Space Law. Position paper on space recourse mining. Adopted by consensus by the Board of Directors on December 20, 2015. https://www.iislweb.org/ docs/SpaceResourceMining.pdf

Jackson, Nicole J., Outer Space in Russia's Security Strategy, Simons Papers in Security and Development, No. 64/2018, School for International Studies, Simon Fraser University, Vancouver, August 2018. https://pdfs.semanticscholar.org/40e4/ d8ee5c172d547fdc4c047ff01b444b69136e.pdf

Jones, Andrew. China Gains New Flexible Launch Capabilities With First Sea Launch. Space. com, 2019. https://www.space.com/china-gains-flexible-capabilities-sea-launch.html

Law of Russia On space activities of August 20, 1993 № 5663-I. (Amended on April 15, 2019). http://docs.cntd.ru/document/9033683

Milton, Smith ("Skip"). A Space Law Primer for Colorado Lawyers Part 2: U.S. FEATURE Space Law, 2018. 43-49. https://www.cobar.org/Portals/COBAR/Repository/TCL/ May\%202018/CL_May_Feature_SpaceLaw.pdf

Soter, Steven and Tyson Neil de Grasse. Cosmic Horizons: Astronomy at the Cutting Edge. New Press, 2000. https://books.google.com.ua/books/about/Cosmic_Horizons. $\mathrm{html}$ ?id=yhx_QgAACAAJ\&redir_esc $=\mathrm{y}$

Space Activities Act 1998 Australia. Act №.123 of 1998 as amended https://www.legislation. gov.au/Details/C2016C01070

Stefoud, Dimitra. 50 years of Space Law: The 1967 Outer Space Treaty. Leiden University. Public Law, 2017 https://leidenlawblog.nl/articles/50-years-of-space-law-the-1967outer-space-treaty

$\mathrm{Su}$, Jinyuan. Legality Of Unilateral Exploitation Of Space Resources Under International Law. International \& Comparative Law Quarterly, Volume 66, Issue 4 October 2017, pp. 991-1008. https://doi.org/10.1017/S0020589317000367

The State Council Information Office of the People's Republic of China. The Information Office of the State Council on Dec. 27 published a white paper on China's space activities in 2016. https://www.scio.gov.cn/zfbps/32832/Document/1537024/1537024.htm

U.S. Code, Title 51, Subtitle II, Chapter 201 - National Aeronautics and Space Program, Subchapters II \& III, Dec. 18, 2010, 124 Stat. 3328. https://wipolex.wipo.int/en/ text $/ 431553$

Zhao, Yun. Space Commercialization and the Development of Space Law. Space Law, Jul 2018. https://doi.org/10.1093/acrefore/9780190647926.013.42 